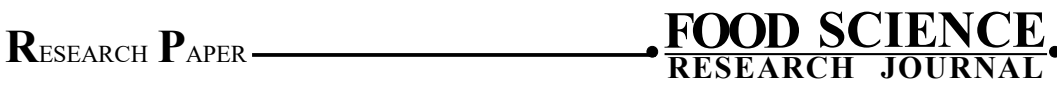

ISSN-0976-1276 - Visit us : www.researchjournal.co.in Volume $11 \mid$ Issue 2 | October, 2020|169-174 DOI : $10.15740 / \mathrm{HAS} / \mathrm{FSRJ} / 11.1 / 169-174$

\title{
To study the attitude on marital adjustment of selected respondents from Mehsana and Ahmadabad city
}

\author{
Jiju N.Vyas, Neha Tiwari and Neeta Chaudhari
}

The present study was conducted in Mehsana (urban and rural area) and Ahmadabad (urban and rural area) city. The sample size was 720 women and they were selected from both the cities. The women who were educated upto $12^{\text {th }}$ standard, graduate and post graduate were randomly selected for the study. Purposive random sampling technique was used for selection of the sample. The research design for the present paper was two pronged approach. A descriptive survey with pre-tested, validated interview schedule was used to acquire the information needed to study the attitude on marital adjustment.

Key Words : Women, Marriage, Education, Goals of marriage, Marital adjustment

How to cite this article : Vyas, Jiju N., Tiwari, Neha and Chaudhari, Neeta (2020). To study the attitude on marital adjustment of selected respondents from Mehsana and Ahmadabad city. Food Sci. Res. J., 11(2): 169-174, DOI : 10.15740/HAS/FSRJ/11.2/169174.Copyright@2020: Hind Agri-Horticultural Society.

Associate Authors' :

Jiju N. Vyas, Aspee College of Home Science and Nutrition, Sardarkrushinagar Dantiwada Agricultural University, Dantiwada (Gujarat) India

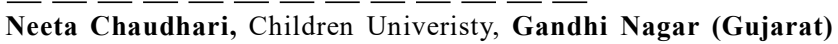
India 